\title{
Cytotoxic effect of the crude extracts of the locally Isolate Lactococcus lactis on AMN-3 tumor cell line
}

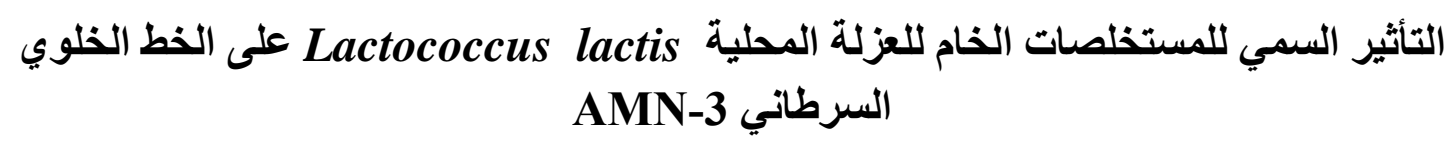

Mohammad R. Abdul-Majeed

Moyassar B. H. Al-Shaibani*

Ali Abbdul-rahman T. Al-Shekhly**

* College of Science/ University of Al-Nahrain

** Biotechnology Research Center/ University of Al-Nahrain

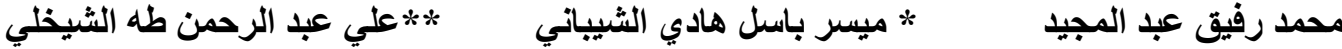

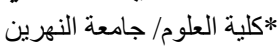

$$
\begin{aligned}
& \text { *** مركز بحوث التقانة الاحيائية / جامعة النهرين النهاين }
\end{aligned}
$$

\section{Abstract}

This project was conducted to study the activity of secondary metabolites produced by one of a human microflora which is Lactococcus lactis on AMN-3 tumour cell line in vitro. Twenty samples of dairy products (bucolic sour yoghurts, pasteurized milk and raw milk) were collected; nine isolates of Lactococccus were isolated by propagating in MRS broth medium followed by subjecting the isolates to microscopic, cultural, physiological and biochemical tests. The results showed the presence of four isolates belonged to the genus Lactococcus sp. lactis. the isolates were grown in in three broth production media, which were MRS, VVM and BHI at $37^{\circ} \mathrm{C}$ for $6 \mathrm{~h}$. followed by extraction of crude extracts using ammonium sulphate saturation ratio which was $80 \%$ for each medium confidentially. The overall result was three crude extracts (one from each medium), followed by estimation the concentrations of extracted proteins depending on standard curve of bovine serum albumin. The cytotoxic activity of different concentrations for each crude extract was studied on $\mathrm{AMN}-3$ tumour cell line for three incubation periods $(24,48,72)$ hrs in addition to normal rabbit embryo fibroblast (REF) cell line for $72 \mathrm{hr}$ only. The result illustrated a clear cytotoxic activity of these crude extracts with high significances on this tumour cell line during the three incubation periods, suggesting that the cytotoxic effect of these crude extracts is a dose and time dependent, but on REF cell line, there is no significant effect of these crude extracts was reported, suggesting also, that may be the active compound of $L$. lactis possess some specificity in cytotoxicity on cancer cells but not on normal cells.

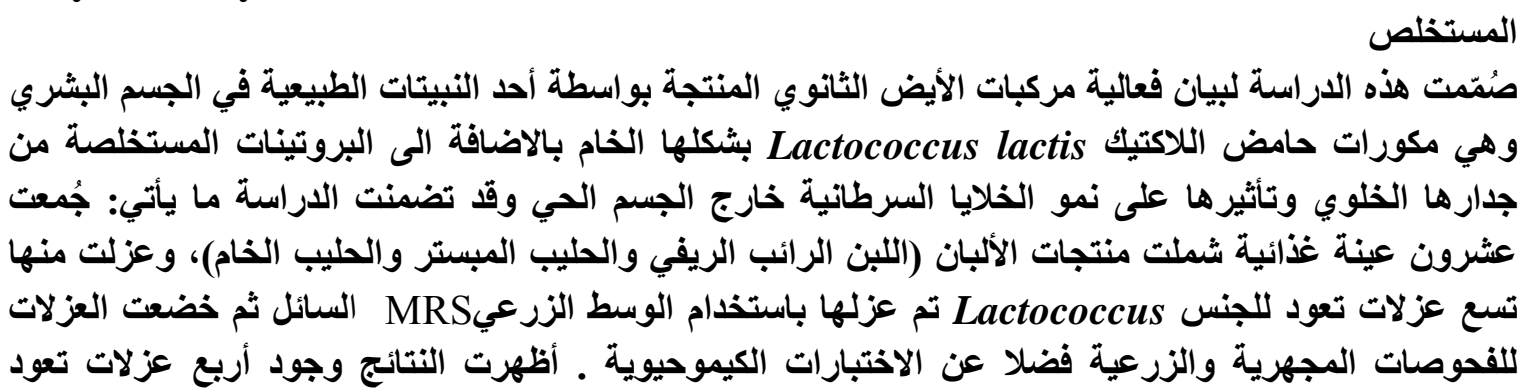

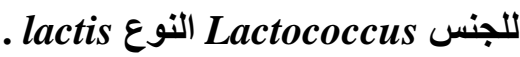




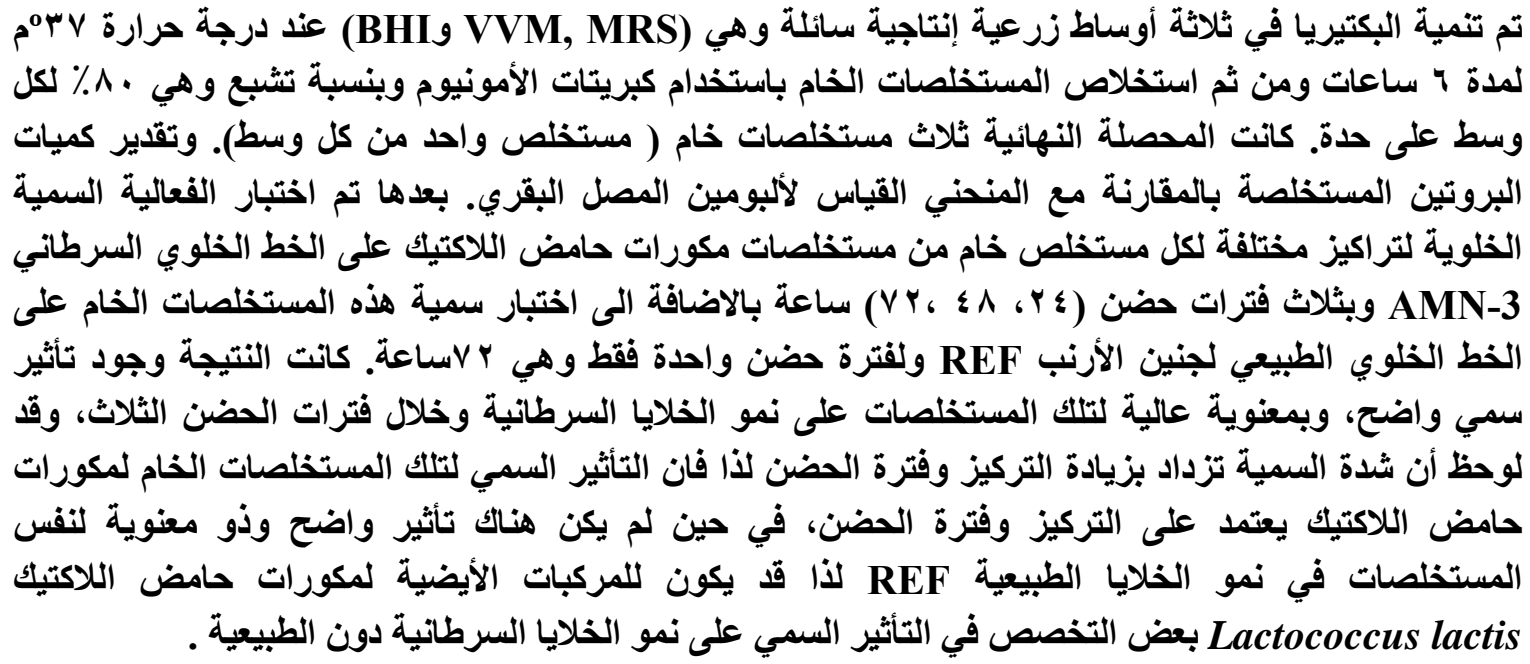

Introduction

The intestinal flora is a complex ecosystem consisting of over 400 bacterial species that greatly outnumber the total number of cells making up the entire human body. These metabolically active bacteria reside close to the absorptive mucosal surface and are capable of a remarkable repertoire of transforming chemical reactions. The esophagus has a flora similar to that of the pharynx [1]. The empty stomach is sterile due to gastric acid. The normal flora of the duodenum, jejunum and upper ileum is scanty but the large intestine is very heavily colonized with bacteria among which are; Bacteriodes (mainly members of the fragilis group which outnumber B. fragilis itself), Bifidobacteria, Anaerobic cocci, E. coli, S. faecalis, Clostridia, Lactobacilli and less common inhabitants; Klebsiellaspp., Proteus spp., Enterobacter spp. and Pseudomonas aeruginosa. The intestinal flora can be thought of as a chemical factory with massive levels of active enzymes. All rapidly growing bacterial species in the small intestines produce metabolic by-products that can be absorbed. Some of the absorbed products are utilized for energy immediately in the epithelial cells of the gut; others may be acted upon by the detoxification systems in the liver; while others are passed [2].

The enteric flora comprises approximately $95 \%$ of the total number of cells in the human body and can elicit immune responses while protecting against microbial pathogens. The beneficial role of the normal flora is the prevention of other more pathogenic bacteria from gaining a foothold in the body. The gut bacteria seem to be responsible for the normal structure and function of the intestine: they degrade mucin, epithelial cells and carbohydrate fiber and their metabolism produces vitamins, especially vitamin $\mathrm{K}$ [3]. However, the resident bacterialflora of the gastrointestinal tract may also be implicated inthe pathogenesis of diseases such as inflammatory bowel disease (ulcerative colitis and Crohn disease). Any compound taken orally, entering the intestine through the biliary tract or by secretion directly into the lumen is a potential substrate for bacterial transformation. So the colonic microflora is important to health [4]. Since the 1980s, many efforts have been made to better understand the molecular basis of LAB technological properties and to obtain better control of industrial processes involving LAB. This knowledge has led researchers to investigate their potential use for new applications, such as the production of heterologous proteins in bioreactors, in fermented food products or directly in the digestive tract of humans and other animals. Some LAB 
used as probiotic strains, naturally exerts a positive action in lactose-intolerant consumers by providing $\beta$-galactosidase in the gut [5]. Besides such natural benefits, another and innovative application of LAB is the antitumor activity to supplement pancreatic and gastrointestinal deficiency in humans [6].

On the strength of those investigations, the present study was proposed for isolation and identification of the species Lactococcus lactis that may possess antitumor activity. Extraction with partial purification of proteins produced by these bacteria in different production media in addition to their cell wall associated proteins followed by in vitro study of the effect of the bacterial crude extracts on the growth of AMN-3 tumor and normal cell lines.

\section{Experimental Work \\ Samples Collection}

Twenty samples of dairy products (bucolic sour yoghurts, pasteurized milk and raw milk) were collected in sterile containers from local markets in Baghdad governorate, followed by propagation the isolates by inoculating test tubes containing MRS broth medium with $1 \%$ of each sample and incubated at $37^{\circ} \mathrm{C}$ for $24 \mathrm{hrs}$ under anaerobic conditions (in an anaerobic jar).

\section{Isolation of Lactic Acid Bacteria}

Lactic acid bacteria were isolated according to Harrigan and MacCance [7], serial dilutions were performed, followed by streaking on MRS agar plates containing 1\% calcium carbonate $\left(\mathrm{CaCO}_{3}\right)$, then incubated at $37^{\circ} \mathrm{C}$ for $24 \mathrm{hrs}$. After that, a loop touch of the growth was transferred to MRS broth and preserved.

\section{Identification of Lactococcus lactis}

The suspected LAB isolates were identified by the following tests:

\section{Microscopic Examination}

A loop full of each isolates culture was fixed on a microscopic slide, and then stained by Gram stain to examine cell shape, Gram reaction, grouping and spore forming phenomena [8].

\section{Biochemical Tests}

The biochemical tests used to identify the locally isolate L. lactis are gelatinase test, catalase test, acid production and clot formation, production of ammonia from arginine, carbohydrates fermentation, growth in $4 \%$ and $6.5 \% \mathrm{NaCl}$, growth in different $\mathrm{pH}$, growth at different temperature and growth in $0.1 \%$ methylene blue [9].

\section{Extraction of Bacterial Secreted Proteins}

Each of MRS, VVM and BHI broth were inoculated with L. lactis and incubated under anaerobic conditions to prevent the production of hydrogen peroxide at $37^{\circ} \mathrm{C}$ for $6 \mathrm{~h}$ to reach production phase. For extraction of protein, a cell free supernatant from each media was obtained by centrifugation at $10,000 \mathrm{rpm}$ for $20 \mathrm{~min}$ at $4^{\circ} \mathrm{C}$ followed by filtration of supernatant through $0.2 \mu \mathrm{m}$ filter unit to get cell free supernatant. The supernatant of each media was independently treated with gradual addition of solid ammonium sulphate saturation ratio $80 \%[10]$.

\section{Quantitative Estimation of Proteins}

Protein concentration was estimated according to Bradford method by using Commassie blue G-250 and Bovine serum albumin (BSA) to determine standard curve and estimate 
protein in concentrated filtrate [11].

\section{Standard Curve of Bovine Serum Albumin}

Bovine serum albumin (BSA) solution was prepared by dissolving $0.1 \mathrm{~g}$ of BSA in a quantity of D.W. and the volume was completed to $100 \mathrm{ml} \mathrm{D.W}$.

Different concentrations of BSA $(2,4,7,10,14,16$ and $20 \mu \mathrm{g} / \mathrm{ml})$ were prepared and plotted [11].

\section{Estimation of Extracted Proteins}

The same steps followed in standard curve were used to determine the protein in concentrated filtrate by taking $20 \mu 1$ from each extract.

\section{Viable Cell Count}

Cells count were performed according to Freshney [12], using try pan blue dye, dead cells take up the dye making them easily distinguished from viable cells. Which counted by Neubauer chamber.

\section{Tumor Inhibition Assay}

The procedure below was depending on cytotoxicity testing mentioned in Freshney [12], AMN-3 cell line which was applied at the passage 50 that represents mammary adenocarcinoma of female mice Balb/c that have in vivo spontaneous mammary adenocarcinoma. On the other hand, rabbit embryo fibroblast (REF) was used as control. Cell suspension of both cell lines were well mixed and treated with different concentrations of each extract which were $(10,5,2.5,1.25,0.625,0.312) \mu \mathrm{g} / \mathrm{ml}$ poured into 96 flat bottom well micro titer plate and incubated at $37^{\circ} \mathrm{C}$ for $(24,48,72) \mathrm{hrs}$ in an incubator supplemented with $5 \% \mathrm{CO}_{2}$. On the other hand, the same cell line (AMN-3) cells was incubated for the same period without treating and used as control. After elapsing the incubation period, $50 \mu \mathrm{l} /$ well of neutral red dye were added and incubated again for $2 \mathrm{hrs}$. The results were read by ELISA reader at $492 \mathrm{~nm}$.

\section{Statistical Analysis}

The results were statistically analyzed to determine the significance effect among the concentrations of both extracts and their effect on tumor cell line and normal cells. The comparison between groups has based on analysis of variance test (ANOVA), while the significance differences based on Duncan's test [13].

\section{Results and Discussion}

The colonies of some isolates on MRS agar by pour plate were circular, white to yellow in color some of which were gray, smooth, mucous, bright and convex, Table (1). These characteristics were the same to those observed when pure culture was obtained using streaking method. It was observed that the growth of LAB on MRS agar was heavier than their growth on SL medium this may be due to the high ratio of sodium acetate and high acidity [14].

Also, there were other isolates their colonies characterized by different shapes (fusiform, ovoid and circular) white to pale in color, soft with smooth edges, non bright and some of which were convex. Such cultural characteristics are concerned with those of the colonies of the genus Lactobacillus [15].

Microscopic examination after Gram staining showed that some suspected cells were spherical, tend to be ovoid, and grouped in pairs, tetrads and short chains, Gram positive and non spore forming, Table (1), these results are supported by those of [16] when they 
isolated 237 isolate of L. lactis among a total of 2000 isolates of LAB obtained from traditional Egyptian dairy products (different types of raw milk, ras, domiatti and kareish cheese, mish, cream, butter and fermented milk) obtained from different regions in Egypt. Also, it was observed that the other isolates that may be belong to the genus Lactobacillus characterized as long curved rods, arranged in short and long chains (3-8) cells and some of which were single and in pairs, Gram positive and non spore forming.

Depending on the results of the cultural and microscopic tests, nine isolates may be belonging to the genus Lactococcus referred to as (Lc1, Lc2, Lc3, Lc4, Lc5, Lc6, Lc7, Lc8, Lc9) and the other tested isolates may be belonging to the genus Lactobacillus. The abundance of the genus Lactococcus in dairy and dairy products is reasonable because they possesses proteinase enzyme system encourage them to grow in milk and its products [17].

Since the present study focused on studying the effect of the crude extract of the genus Lactococcus on tumor cell lines, so we restricted the biochemical tests on these suspected isolates ignoring the others.

Table (1): Morphological and Cultural Taxonomic Characteristics of the Suspected Isolates.

\begin{tabular}{lc}
\hline \multicolumn{1}{c}{ Characteristics } & Results \\
1- Gram stain & G +ve \\
2- Cell shape & Spherical to oval \\
3- Grouping & Single, in pairs and short chains \\
4-Colony shape on MRS and SL agar & Circular, small, regular, convex with smooth \\
5- Motility & Non motile \\
6- Growth under aerobic conditions & + \\
7- Growth under anaerobic & + \\
conditions & \\
\hline$+=$ Presence of growth
\end{tabular}

Biochemical characteristics shown in Table (2) demonstrated that each of the nine isolates were catalase negative since no bubbles were observed after addition of hydrogen peroxide, gelatinase negative, and the isolates (Lc1, Lc4, Lc5 and Lc8) produced ammonia from arginine due to the presence of arginine deiminase which isone of three enzymes that comprise the $\mathrm{AD}$ system, $\mathrm{AD}$ catalyzes the conversion of L-arginine to citrulline, with the concomitant production of ammonia [18]. Also these four isolates have grown in $0.1 \%$ methylene blue with reduction of dye with tenuous growth in $4 \% \mathrm{NaCl}$ while the growth was lacking in $6.5 \% \mathrm{NaCl}$ and $45^{\circ} \mathrm{C}$ and produced acid and formed clot in litmus milk causing the lowering of $\mathrm{pH}$ from 6.5 to 4.5, while other isolates ( $\mathrm{Lc} 2, \mathrm{Lc} 3$, Lc6, Lc7 and Lc9) did not produce ammonia from arginine due to the stability of the orange color of the medium, and lacked the ability to grow in $4 \% \mathrm{NaCl}$ as well as inability to grow in $0.1 \%$ methylene blue, also, all isolates taken part in their inability to grow at $45^{\circ} \mathrm{C}$ and $\mathrm{pH} 9.5$ but have grew at $\mathrm{pH} 9$, facultative anaerobic since it had the ability to grow under aerobic and anaerobic conditions and can grow at $(10-40)^{\circ} \mathrm{C}$, these results are in agreement with taxonomic characteristics of the genus Lactococcus which were mentioned by [16].

In order to differentiate the nine isolates of Lactococcus species, carbohydrates fermentation test was performed. The isolates were different in their ability to ferment the carbohydrates source used. The isolates (Lc2, Lc3, Lc6 Lc7, Lc9) which fermented 
(glucose, sucrose, lactose, mannose, mannitol, galactose, maltose and raffinose) but varied in their ability to ferment arabinose and xylose were identified as Lactococcusraffinolactis. While the isolates (Lc1, Lc4, Lc5, Lc8) vary in their ability to ferment xylose while unable to ferment arabinose and raffinose but have fermented the other used saccharides were identified as L. lactis [19].

According to the results above, the overall resultant was nine isolates of Lactococcus; five of them (Lc2, Lc3, Lc6 Lc7 and Lc9) were identified as Lactococcus sp. Raffinolactis and the others (Lc1, Lc4, Lc5, Lc8) were identified as Lactococcus sp. lactis. Our study focused on studying the effect of the crude extracts of the genus Lactococcus sp. lactis ignoring the species raffinolactis.

Table (2): Biochemical tests of the locally Lactococcus Isolates.

\begin{tabular}{|c|c|c|c|c|c|c|c|c|c|c|c|c|c|c|c|c|c|c|}
\hline \multirow[b]{2}{*}{$\begin{array}{l}\frac{9}{\tilde{N}} \\
\dot{\theta} \\
0\end{array}$} & \multirow{2}{*}{ 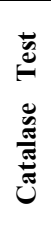 } & \multirow[b]{2}{*}{ 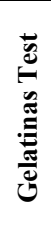 } & \multirow{2}{*}{ 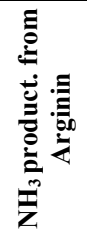 } & \multirow{2}{*}{ 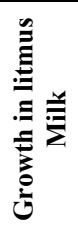 } & \multicolumn{3}{|c|}{ Growth at } & \multirow{2}{*}{ 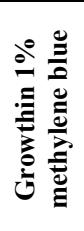 } & \multicolumn{10}{|c|}{ Acid Production from } \\
\hline & & & & & $\begin{array}{l}0 \\
\stackrel{0}{\varrho}\end{array}$ & $\begin{array}{l}\text { Q } \\
\stackrel{f}{q}\end{array}$ & $\begin{array}{l}\text { if } \\
\text { if }\end{array}$ & & $\begin{array}{l}\stackrel{\Xi}{0} \\
\stackrel{0}{E} \\
\stackrel{\Xi}{0}\end{array}$ & $\begin{array}{l}\mathscr{0} \\
\stackrel{0}{0} \\
\ddot{\Xi}\end{array}$ & 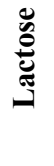 & $\stackrel{\mathscr{E}}{\tilde{\Sigma}}$ & $\bar{\Xi}$ & $\vec{E}$ & $\vec{x}$ & $\bar{\Xi}$ & $\bar{\Sigma}$ & 气 \\
\hline Le1 & - & - & + & + & + & + & - & + & + & + & + & + & + & - & + & + & + & - \\
\hline Lc2 & - & - & - & + & - & + & - & - & + & + & + & + & + & - & + & + & + & + \\
\hline Lc3 & - & - & - & + & - & + & - & - & + & + & + & + & + & - & + & + & + & + \\
\hline Lc4 & - & - & + & + & + & + & - & + & + & + & + & + & + & - & + & + & + & - \\
\hline Le5 & - & - & + & + & + & + & - & + & + & + & + & + & + & - & - & + & + & - \\
\hline Le6 & - & - & - & + & - & + & - & - & + & + & + & + & + & - & + & + & + & + \\
\hline Lc7 & - & - & - & + & - & + & - & - & + & + & + & + & + & + & + & + & + & + \\
\hline Le8 & - & - & + & + & + & + & - & + & + & + & + & + & + & - & + & + & + & - \\
\hline Lc9 & - & - & - & + & - & + & - & - & + & + & + & + & + & + & - & + & + & + \\
\hline
\end{tabular}

The standard curve of bovine serum albumin was plotted and figure (1) explains this curve.

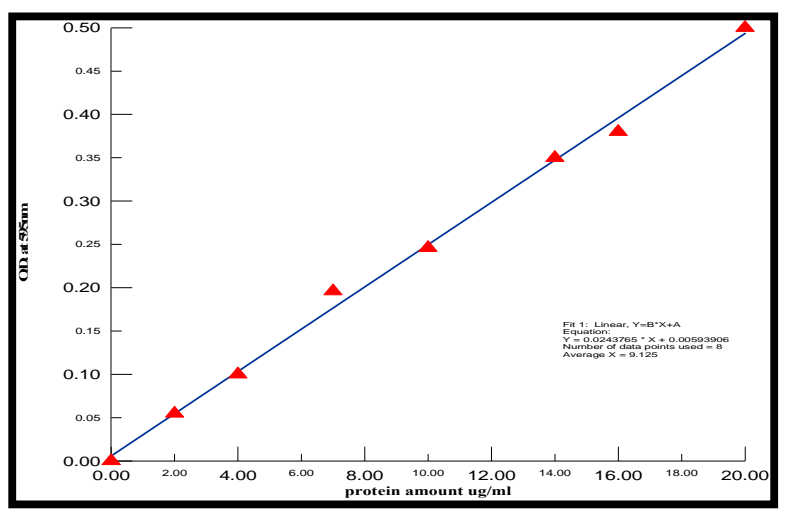

Figure (1): Standard curve of Bovine Serum Albumin.

\section{Extraction and Purification of Extracted Proteins}

The results were three extracts (one from each medium) in addition to CWP; these extracts have given termed according to the production medium and the saturation ratio with the ammonium sulphates as follow:

- M6-80: Proteins extracted from L. Lactis grown in MRS broth for $6 \mathrm{hr}$ with $80 \%$ ammonium sulphate saturation ratio.

- B6-80: Proteins extracted from L. lactis grown in BHI broth for $6 \mathrm{hr}$ with $80 \%$ ammonium sulphate saturation ratio.

- V6-80: Proteins extracted from L. lactis grown in VVM broth for $6 \mathrm{hr}$ with $80 \%$ ammonium sulphate saturation ratio. 
Table (3): The Concentrations of total proteins in supernatants of the locally isolate L. lactis protein production media.

\begin{tabular}{ccc}
\hline TheCrude Extracts & O.D. $(595 \mathrm{~nm})$ & Protein concentration $(\mu \mathrm{g} / \mathrm{ml})$ \\
M6-80 & 0.401 & 16.226 \\
B6-80 & 0.330 & 13.299 \\
V6-80 & 0.372 & 15.034 \\
\hline
\end{tabular}

\section{The Concentrations of Extracted Proteins}

When compared with standard curve of BSA, the concentrations of extracted proteins were variant; these variations may be due to the type of production media and saturation ratio with ammonium sulphate. The production was highest in MRS broth and this compatible with Boutrou [20] who observed that several of the proteins were present in abundance in the supernatants of mid-log-phase cultures of MRS broth medium when compared with other production media such as GM17 and chemically defined medium (CDM) containing glucose, this probably due to the inactivation of the proteins by the proteolytic / peptidolytic system of the producer cells by the ingredients of these media. Along with Lei et al., [21], the lesser production was in the BHI broth medium who observed that the production of proteins was lower in BHI broth supplemented with erythromycin $10 \mu \mathrm{g} / \mathrm{ml}$ or spectinomycin $100 \mu \mathrm{g} / \mathrm{ml}$ when compared with that of LuriaBertani (LB) medium supplemented with ampicillin $(100 \mu \mathrm{g} / \mathrm{ml})$, Table (4).

Table (4): The Concentrations of total proteins extracted from the locally isolate L. lactis after precipitation with ammonium sulphate.

\begin{tabular}{ccc}
\hline The Crude Extracts & O.D. $(595 \mathrm{~nm})$ & Protein concentration $(\mu \mathrm{g} / \mathrm{ml})$ \\
M6-80 & 0.331 & 13.572 \\
B6-80 & 0.251 & 10.053 \\
V6-80 & 0.302 & 12.145 \\
\hline
\end{tabular}

On the other hand, Partial purification of the proteins was carried out by precipitation with ammonium sulphate. In addition to purification, this step leads to considerable lose in the concentrations of extracted protein when compared between Table $(3,4)[22]$.

\section{The Effects of the Crude Extracts of L. lactis on AMN-3 Cell Line}

The results showed that there was an obvious cytotoxic effect for these concentrations in the growth of AMN-3 cell line during the three periods of incubation that has started at certain concentrations and continued to the higher concentrations reaching the last concentration when compared with the control. Also, it was observed that there were variations in cytotoxic effect between one extract and another and among the concentrations of the same extract but at different periods of incubation, Table (5).

Table (5): The concentrations of the crude extracts of the locally isolate $L$. lactis at which the cytotoxic effect on AMN-3 cell line has started after incubation for different periods.

\begin{tabular}{cccc}
\hline The Crude & \multicolumn{3}{c}{ The concentrations $(\mu \mathrm{g} / \mathrm{ml})$ at which the cytotoxic effect has started after: } \\
Extracts & $24 \mathrm{~h}$ & $48 \mathrm{~h}$ & $72 \mathrm{~h}$ \\
M6-80 & 1.25 & 0.625 & 0.625 \\
B6-80 & 2.5 & 1.25 & 0.625 \\
V6-80 & 1.25 & 0.625 & 0.625 \\
\hline
\end{tabular}




\section{The Effect of the Crude Extract M6-80}

As shown in Table (6), this crude extract has cytotoxic effect in the growth of AMN-3 cell line starting at the concentration $1.25 \mu \mathrm{g} / \mathrm{ml}$ with high significance difference $(\mathrm{P} \leq 0.001)$ accompanied with increased cytotoxic effect toward the higher concentrations when compared with the control (the same cell line treated with SFM only) during the incubation period $24 \mathrm{hr}$. The concentration $0.625 \mu \mathrm{g} / \mathrm{ml}$ has cytotoxic effect in the growth of this cell line at $48 \mathrm{hrs}$ incubation period with high significant difference $(\mathrm{P} \leq 0.001)$ with increased cytotoxic effect toward the higher concentrations when compared with the control. While during the incubation period $72 \mathrm{hrs}$, the cytotoxic effect has started at the concentration $0.625 \mu \mathrm{g} / \mathrm{ml}$ with high significant difference $(\mathrm{P} \leq 0.001)$ with increased cytotoxic effect toward the higher concentrations when compared with the control.

Table (6): The effect of M6-80 on $\mathrm{AMN}-3$ cell line

\begin{tabular}{|c|c|c|c|c|}
\hline \multirow{2}{*}{ Group } & \multirow{2}{*}{$\begin{array}{l}\text { Conc. } \\
(\mu \mathrm{g} / \mathrm{ml})\end{array}$} & \multicolumn{3}{|c|}{ O.D. Mean $\pm\left(\operatorname{SE} \times 10^{-3}\right)$ at different incubation periods } \\
\hline & & After $24 \mathrm{hrs}$ & After $48 \mathrm{hrs}$ & After $72 \mathrm{hrs}$ \\
\hline \multirow{6}{*}{ Treated } & 0.312 & $0.44100 \pm 3.215^{\mathrm{a}}$ & $0.42533 \pm 3.845^{a}$ & $0.40433 \pm 3.285^{\mathrm{a}}$ \\
\hline & 0.625 & $0.43500 \pm 2.673^{a}$ & $* 0.38900 \pm 7.638^{b}$ & $* 0.37200 \pm 8.082^{b}$ \\
\hline & 1.25 & $* 0.40700 \pm 3.054^{b}$ & $0.37433 \pm 6.766^{b}$ & $0.32400 \pm 5.565^{c}$ \\
\hline & 2.5 & $0.39400 \pm 0.011^{b}$ & $0.32067 \pm 8.873^{c}$ & $0.29533 \pm 4.255^{d}$ \\
\hline & 5 & $0.36100 \pm 5.294^{\mathrm{c}}$ & $0.27700 \pm 5.860^{d}$ & $0.29100 \pm 6.027^{d}$ \\
\hline & 10 & $0.27900 \pm 5.132^{d}$ & $0.25133 \pm 7.309^{\mathrm{e}}$ & $0.21600 \pm 4.041^{\mathrm{e}}$ \\
\hline Control I & & $0.44500 \pm 1.997$ & $0.43200 \pm 2.644$ & $0.41300 \pm 3.510$ \\
\hline
\end{tabular}

*different letters $=$ significant differences $(\mathrm{P}<0.05)$ between mean.

\section{The Effect of the Crude Extract B6-80}

Cytotoxic effect of this crude extract on the growth of AMN-3 cell line has obviously appeared after $24 \mathrm{hrs}$ of incubation with high significant difference $(\mathrm{P} \leq 0.001)$ at the concentration $2.5 \mu \mathrm{g} / \mathrm{ml}$ with increased cytotoxic effect toward the higher concentrations when compared with the control. At $48 \mathrm{hrs}$ incubation period, the cytotoxic effect has started with significance difference $(\mathrm{P} \leq 0.001)$ at the concentration $1.25 \mu \mathrm{g} / \mathrm{ml}$ with increasing toward the higher concentrations when compared with the control. While during the incubation period $72 \mathrm{hrs}$, the cytotoxic effect with significance difference $(\mathrm{P} \leq 0.001)$ has started at the concentration $0.625 \mu \mathrm{g} / \mathrm{ml}$ attended with increased cytotoxic effect toward the higher concentrations when compared with the control, Table (7).

Table (7): The effect of B6-80 on AMN-3 cell line

\begin{tabular}{|c|c|c|c|c|}
\hline \multirow{2}{*}{ Group } & \multirow{2}{*}{ Conc. $(\mu \mathrm{g} / \mathrm{ml})$} & \multicolumn{3}{|c|}{ O.D. Mean $\pm\left(\mathrm{SE} \times 10^{-3}\right)$ at different incubation periods } \\
\hline & & After 24 hrs & After 48 hrs & After 72 hrs \\
\hline \multirow{6}{*}{ Treated } & 0.312 & $0.44567 \pm 5.455^{a}$ & $0.44200 \pm 5.565^{a}$ & $0.43400 \pm 5.565^{\mathrm{a}}$ \\
\hline & 0.625 & $0.43000 \pm 6.246^{\mathrm{a}}$ & $0.41800 \pm 5.565^{a}$ & $* 0.40200 \pm 7.095^{b}$ \\
\hline & 1.25 & $0.42200 \pm 8.019^{a}$ & $* 0.37400 \pm 7.095^{b}$ & $0.38000 \pm 6.558^{c}$ \\
\hline & 2.5 & $* 0.39700 \pm 2.517^{b}$ & $0.38600 \pm 4.728^{b}$ & $0.35000 \pm 7.026^{d}$ \\
\hline & 5 & $0.37600 \pm 5.132^{c}$ & $0.36400 \pm 5.565^{c}$ & $0.28067 \pm 6.010^{e}$ \\
\hline & 10 & $0.32300 \pm 7.026^{d}$ & $0.28400 \pm 5.132^{d}$ & $0.24567 \pm 5.455^{f}$ \\
\hline Control I & & $0.44700 \pm 4.162$ & $0.44167 \pm 3.931$ & $0.43567 \pm 5.445$ \\
\hline
\end{tabular}

*different letters $=$ significant differences $(\mathrm{P}<0.05)$ between mean.

\section{The effect of the crude extract V6-80}

Cytotoxic effect of this crude extract has started with high significant difference $(\mathrm{P} \leq 0.001)$ at the concentration $1.25 \mu \mathrm{g} / \mathrm{ml}$ toward the higher concentrations when compared with the control during the incubation period $24 \mathrm{hrs}$. At incubation period 48 
hrs, cytotoxic effect with high significant difference $(\mathrm{P} \leq 0.001)$ was at the concentration $0.625 \mu \mathrm{g} / \mathrm{ml}$ toward the higher concentrations when compared with the control. While during the incubation period $72 \mathrm{hrs}$, the cytotoxic effect with high significant difference $(\mathrm{P} \leq 0.001)$ has started at the concentration $0.625 \mu \mathrm{g} / \mathrm{ml}$ with increased cytotoxic effect toward the higher concentrations when compared with the control, Table (8).

Table (8): The effect of V6-80 on AMN-3 cell line

\begin{tabular}{|c|c|c|c|c|}
\hline \multirow{2}{*}{ Group } & \multirow{2}{*}{$\begin{array}{l}\text { Conc. } \\
(\mu \mathrm{g} / \mathrm{ml})\end{array}$} & \multicolumn{3}{|c|}{ O.D. Mean $\pm\left(\operatorname{SE~} \times 10^{-3}\right)$ at different incubation periods } \\
\hline & & After 24 hrs & After 48 hrs & After 72 hrs \\
\hline \multirow{6}{*}{ Treated } & 0.312 & $0.46800 \pm 2.084^{a}$ & $0.45667 \pm 3.279^{a}$ & $0.42200 \pm 5.132^{a}$ \\
\hline & 0.625 & $0.45833 \pm 2.904^{a}$ & $* 0.41400 \pm 4.041^{b}$ & $* 0.38400 \pm 5.686^{b}$ \\
\hline & 1.25 & $* 0.42600 \pm 4.584^{b}$ & $0.41500 \pm 3.510^{b}$ & $0.32000 \pm 6.656^{\mathrm{c}}$ \\
\hline & 2.5 & $0.42267 \pm 5.363^{c}$ & $0.36500 \pm 5.565^{b}$ & $0.27200 \pm 7.551^{\mathrm{c}}$ \\
\hline & 5 & $0.39000 \pm 3.510^{d}$ & $0.32000 \pm 0.010^{b}$ & $0.25400 \pm 4.509^{d}$ \\
\hline & 10 & $0.35200 \pm 2.084^{e}$ & $0.30900 \pm 6.108^{c}$ & $0.20000 \pm 9.607^{\mathrm{e}}$ \\
\hline Control I & & $0.47000 \pm 4.584$ & $0.46200 \pm 4.162$ & $0.45900 \pm 5.034$ \\
\hline
\end{tabular}

Our findings consistent to those gained by [23] who showed that Streptococcus pyogenes (group A Streptococcus) cell extracts (CE) at concentrationsabove $0.5 \mu \mathrm{g} / \mathrm{ml}$ among the used concentrations $(0,0.008,0.04,0.2,0.5,1.0$, and $5.0 \mu \mathrm{g} / \mathrm{ml})$ consistently caused potent inhibition of T-cellproliferation in vitro during three days incubation period. Streptococcal acid glycoprotein (SAGP); this protein possesses between 31.5 and $39.0 \%$ amino acid identity with arginine deiminase (AD) with native molecular mass has been reported as 140 to $150 \mathrm{kDa}$ and also $220 \mathrm{kDa}$ [24]. AD is one of three enzymes that comprise the $\mathrm{AD}$ system. $\mathrm{AD}$ catalyzes the conversion of L-arginine to citrulline, with the concomitant production of ammonia. The $\mathrm{AD}$ system is widely distributed among prokaryotes, including Enterococcus faecalis, L. lactis, Enterococcus faecium, and Clostridium perfringens, and in Mycoplasma the catabolism of L-arginine by this enzyme complex acts as a major nonglycolytic metabolic energy source. Purified group A streptococcal AD have all been shown to be dimers composed of two identical subunits with molecular masses in the range of 46 to $54 \mathrm{kDa}$ [18]. AD has been well documented as having antiproliferative activity against a range of tumor cell lines, including murine fibrosarcoma Meth A cells, human HL60 cells, murine embryonic cells (BALB/3T3), HeLa cells, and murine leukemic L1210 cells, SAGP has been used clinically as an antitumor agent, but it appears to mediate its tumouricidal effect by modulating the host immune response through pathways not involving the activity of SAGP. Lyophilized preparation of SAGP (OK-432) is known to activate natural killer cells, T cells, and macrophages in vitro, and animals treated with OK-432 intraperitoneally develop antitumor cytotoxic macrophages, also, SAGP is reported to have a direct cytotoxic effect on tumor cell lines [25]. In vitro, L-arginine is essential for the optimal growth and proliferation of cells, but lack of extracellular L-arginine in the growth medium is thought not to lead to cell death. The action of AD will lead to a depletion of L-arginine in growth media, and may be in the absence of L-arginine cells are simply unable to synthesize new proteins, thus inhibiting growth and proliferation [23]. Since L. lactis is a genus of group A streptococci so their inhibitory effect in the growth of tumor cell lines may be attributed to this active compound (SAGP). 
Cancer cells possesses metabolic characteristics unavailable in normal cells; including opportunism, fastidious nutrition requirements and the ability for invasion and distribution, this require the presence of specific genes or proteins differ from those of normal cells so, the cancer cells perhaps be a target for the active compounds of the secondary metabolites e.g., the formation of free radicals during lipid peroxidation which is considered an important step to provide energy during the transformation of the normal cells to cancer cells [26]. So, the active components of the secondary metabolites of the studied bacteria may play an important role in their cytotoxic effect in cancer cells by retarding the activity of lipoxygenase via inhibition 5-lipoxygenase mRNA which is overexpressed in cancer cells, that by role inhibits topoisomerase I responsible for DNA replication and then cell proliferation which lead the cell to reach PCD [27].

The effect of the crude extract of $L$. lactis on normal rabbit embryo fibroblast (REF) Statistical analysis has showed that there is no significant difference $(\mathrm{P} \leq 0.039)$ for each concentration of these crude extracts when compared with both control I and control II indicating that these crude extracts have no lucid effect on the growth of REF cell line after incubation period for $72 \mathrm{hrs}$, Table (9).

Table (9): A comparison between the effect of the crude extracts of $L$. lactis on AMN-3 cell line and REF for 72 hrs

\begin{tabular}{|c|c|c|c|c|}
\hline \multirow{2}{*}{ Group } & \multirow{2}{*}{$\begin{array}{c}\text { Conc. } \\
(\mu \mathrm{g} / \mathrm{ml})\end{array}$} & \multicolumn{3}{|c|}{ O.D. Mean $\pm\left(\right.$ SE $\left.\times 10^{-3}\right)$ at 72 hrs } \\
\hline & & M6-80 & B6-80 & V6-80 \\
\hline \multirow{6}{*}{ Treated } & 0.312 & $0.40433 \pm 3.285^{\mathrm{a}}$ & $0.43400 \pm 5.565^{a}$ & $0.42200 \pm 5.132^{a}$ \\
\hline & 0.625 & $* 0.37200 \pm 8.082^{b}$ & $* 0.40200 \pm 7.095^{b}$ & $* 0.38400 \pm 5.686^{b}$ \\
\hline & 1.25 & $0.32400 \pm 5.565^{c}$ & $0.38000 \pm 6.558^{c}$ & $0.32000 \pm 6.656^{c}$ \\
\hline & 2.5 & $0.29533 \pm 4.255^{d}$ & $0.35000 \pm 7.026^{d}$ & $0.27200 \pm 7.551^{\mathrm{c}}$ \\
\hline & 5 & $0.29100 \pm 6.027^{d}$ & $0.28067 \pm 6.010^{\mathrm{e}}$ & $0.25400 \pm 4.509^{d}$ \\
\hline & 10 & $0.21600 \pm 4.041^{e}$ & $0.24567 \pm 5.455^{f}$ & $0.20000 \pm 9.607^{\mathrm{e}}$ \\
\hline REF & & $0.43087 \pm 4.361^{\mathrm{a}}$ & $0.42398 \pm 6.393^{a}$ & $0.45879 \pm 5.483^{a}$ \\
\hline
\end{tabular}

*different letters $=$ significant differences $(\mathrm{P}<0.05)$ between mean.

There was no effect or slight effect without significance on the growth of REF cell line, this selectivity may be attributed to the metabolic behavior possessed by cancer cells rather than in normal cells such as metabolic nature to form new blood vessels, the shape and nature of the receptors presents on the surface of cancer cell and the ability to bind with different compounds [28]. In addition, in cancer cells DNA strands are relaxant and the whole molecule is unstable due to the distance between the hydrogen bonds (H-bonds) that bind the two strands together this facilitates the binding of intra- and extracompounds with DNA strands while in normal cells DNA molecule is cohesive and Hbonds are close to each other this prevent the binding of other foreign compounds [29].

\section{Conclusions}

The crude extracts M6-80, V6-80 and B6-80 of L. lactis possess conspicuous cytotoxic effect in growth inhibition of AMN-3 tumour cell line in vitro depending on both concentration and time. On the other hand, these crude extracts have no cytotoxic effect with observed significance differences in the growth of normal rabbit embryo fibroblast (REF) cell line.

\section{References}

1. Bralley, J. A. and Lord, R. S. (2005). New Laboratory Measures for Detection of Abnormal Microbial Growth. 76(4): 376-90. 
2. Dunne, C., O'Mahony, L., Murphy, L., Thornton, G., Morrissey, D., O'Halloran, S., Feeney, M., Flynn, S., Fitzgerald, G., Daly, C., Kiely, B., O'Sullivan, G. C., Shanahan, F. and Collins, J. K. (2001). In vitro selection criteria for probiotic bacteria of human origin: correlation with in vivo findings. Am. J. Clin. Nutr., 73 (2): 386-392.

3. Burns, A. J. and Rowland, I. R. (2000). Anti-carcinogenicity of probiotics and prebiotics. Curr. Issues Intest. Microbiol., 1 (1): 13-24.

4. Macfarlane, G. T. and Cummings, J. H. (2003). Probiotics and prebiotics: can regulating the activities of intestinal bacteria benefit health? Education and debate. BMJ. 318(11): 999-1003.

5. Seegers, J. F. (2002). Lactobacilli as live vaccine delivery vectors: progress and prospects. Trends Biotechnol. 20: 508-515.

6. Drouault, S., Juste, C., Marteau, P., Renault, P. and Corthier, G. (2002). Oral treatment with Lactococcus lactis expressing Staphylococcus hyicus lipase enhances lipid digestion in pigs with induced pancreatic insufficiency. Appl. Environ. Microbiol. 68: 3166-68.

7. Harrigan, W. F. and McCane, M. E. (1976). Laboratory methods in foods and dairy microbiology. Academic Press. London.

8. Garvie, E. I. (1986). Genus Leuconostoc. In: Bergeys Manual of Systematic Bacteriology. Sneath, P. H. A., Mair, N. S. and Hold, J. G. (eds.). Williams and Wilkinsco, 2 Baltimore. M. D. USA.

9. Al-Dulaimy, G. A. (2000). Using ethanol for isolation of lactic acid bacteria and studying synergistic effect with baker's yeast against some test bacteria. M.Sc. thesis, Dept. of Food Technology, College of Agriculture/University of Baghdad. (in Arabic).

10. Ko, S. H. and Ahn, C. (2000). Bacteriocin production by Lactococcus lactis KCA 2386 isolated from white kimchi. Food Sci. Biotechnol. 9(4): 263-269.

11. Bradford, M. M. (1976). A rapid and sensitive method for the quantitation of microgram quantities of protein utilizing the principle of protein-dye binding. Anal. Biochem. 72: 248-254.

12. Freshney, R. I. (2000). Culture of animal cells: A manual of basic technique (4 $4^{\text {th. }}$ Ed.). Wiley-Liss, A. and Wiley, J. (eds.). Inc. publication. New York, U.S.A.

13. AL-Mohammed, N. T., AL-Rawi, K. M., Younis, M. A. and AL-Morani, W. K. (1986). Principles of statistics. AL-Mosil University.

14. Chapman, H. R. and Sharpe, M. E. (1981). Microorganism in Cheese. In: Dairy Microbiology. (2 ${ }^{\text {nd. }}$ Ed.). Robinson, R. K. (ed.). Applied Science Publishers. London and New Jersey.

15. Kandler, O. and Weiss, N. (1986). Genus Lactobacillus. In: Bergeys Manual of Systematic Bacteriology. Sneath, P. H. A.; Mair, N. S. and Hold, J. G. (eds.). Vol. 2, William and Wilkins co., Baltimore. M. D. USA.

16. El Soda, M., Ahmed, N., Omran, N., Osman, G. and Morsi, A. (2004). Isolation, identification and selection of lactic acid bacteria cultures for cheesemaking. Emir. J. Agric. Sci. 15(2): 51-71. 
17. Hayes, F., Caplice, E., Mcsweeney, A. and Daly, C. (1990). PAMB1. Associated mobilization of proteinase plasmids from Lactococcus lactis UC317 and Lactococcus lactis sp. UC205. Appl. Environ. Microbiol. 56: 195-201.

18. Misawa, S., Aoshima, M., Takaku, H., Matsumoto, M. and Hayashi, H. (1994). Highlevel expression of Mycoplasma arginine deiminase in Escherichia coli and its efficient renaturation as an anti-tumor enzyme. J. Biotechnol. 36: 145-155.

19. Teuber, M. (1995). The Genus Lactococcus. In: The Genera of Lactic Acid Bacteria. Wood, B. J. and Holzapfel, W. H. (eds.).

20. Boutrou, R., Sepulchre, A., Grippon, J. C. and Monet, V. (1998). Simple tests for predicting the lytic behavior and proteolytic activity of lactococcal strains in cheese. J. Dairy Sci. 81: 2321-28.

21. Lei, B., Mackie, S., Lukomski, S. and Musser, J. M. (2000). Identification and immunogenicity of group A Streptococcus culture supernatant proteins. Infect. Immun. 68(12): 6807-18.

22. Ivanova, K., Kabadjova, A., Panter, A., Danova, S. and Dousset, X. (2000). Detection, purification and partial characterization of a noval, Bacteriocin subsp. Latis B14 isolated from Bosa-Bulgarian Traditional cereal Beverages: Biocatalysis, Fundamentals and applications. 41(6): 47-53.

23. Degnan, B. A., Fontaine, M. C., Doebereiner, A. H., Lee, J. J., Mastroeni, P., Dougan, G., Goodacre, J. A. and Kehoe, M. A. (2000). Characterization of an isogenic mutant of Streptococcus pyogenes Manfredo lacking the ability to make streptococcal acid glycoprotein. Infect. Immun. 68:2441-48.

24. Yoshida, J., Takamura, S., Suzuki, S. and Nishio, M. (1996). Streptococcal glycoprotein-induced tumor cell growth inhibition involves the modulation of a pertussis toxin-sensitive G protein. British J. Cancer. 73: 917-923.

25. Curran, T. M., Lieou, J. and Marquis, R. E. (1995). Arginine deiminase system and acid adaptation of oral streptococci. Appl. Environ. Microbiol. 61: 4494-96.

26. Gargalovic, P. and Dory, L. (2003). Cellular apoptosis is associated with increased caveolin-1 expression in macrophages. J. Lipid Res. 44: 1622-32.

27. Hetts, S. W. (1998). To die or not to die: an overview of apoptosis and its role in disease. JAMA. 279: 300-307.

28. Moteki, H., Hibasami, H., Yamada, Y., Katsuzaki, H., Imai, K. and Komiya, T. (2002). Specific induction of apoptosis 1,8 - cineole in two human leukemia cell lines, but not in a human stomach cancer cell lines. Oncology Rep. 9: 757-760.

29. Belijanski, M. (2000). The anticancer agent PB-100 selectivity active malignant cell inhibits multiplication of sixteen malignant cell lines, even multidrug resistant. Genet. Mol. Biol. 23: 224-235. 